\title{
Katarzyna Haremska
}

\section{Społeczny wymiar natury ludzkiej - konsekwencje i wyzwania}

Część zwierząt żyje samotnie, nie odczuwając potrzeby obecności innych podobnych sobie istot. Bóg jest samotny $z$ definicji. Człowiek pozostawiony został w sferze pomiędzy - wzniósł się ponad poziom zwierzęcy, a nie dorósł do boskiego. Do realizacji pełni swego człowieczeństwa potrzebuje kontekstu społecznego. Świat przyjął tę Arystotelesowska diagnozę kondycji ludzkiej ${ }^{1} \mathrm{w}$ zasadzie bezkrytycznie. Ci, którzy ją odrzucili, byli nieliczni i nie znaleźli naśladowców.

\section{Inni}

Bycie istota społeczną oznacza bytowa niesamoistność. Potrzebujemy innych $z$ wielu względów. Po pierwsze dlatego, że w surowych ziemskich warunkach nie poradzilibyśmy sobie sami. Egzystencjalna niesamodzielność jednostek wymaga podziału pracy

Katarzyna Haremska (ORCID 0000-0001-8710-1805) - doktor habilitowana, pracuje w Katedrze Filozofii Społecznej w Instytucie Filozofii i Socjologii Uniwersytetu Pedagogicznego w Krakowie.

1 „Kto zaś nie potrafi żyć we wspólnocie albo jej wcale nie potrzebuje, będąc samowystarczalnym, bynajmniej nie jest członem państwa, a zatem jest albo zwierzęciem, albo bogiem. Wszystkim ludziom właściwy jest $z$ natury pęd do życia we wspólnocie”. Arystoteles, Polityka, w: idem, Dzieła wszystkie, t. 6, przeł. L. Piotrowicz, Wydawnictwo Naukowe PWN, Warszawa 2001, 1253a, s. 28. 
i wymiany usług. Taka była według Platona przyczyna powstania pierwszej wspólnoty ludzkiej: „[...] państwo tworzy się dlatego, że żaden $z$ nas nie jest samowystarczalny, tylko mu potrzeba wielu innych. [...] Więc tak, bierze jeden drugiego do tej, a innego do innej potrzeby, a że wielu rzeczy potrzebujemy, więc zbieramy wielu ludzi do jednego siedliska, aby wspólnie żyli i pomagali jeden drugiemu, i to wspólne mieszkanie nazwaliśmy imieniem państwa"2.

Po drugie, społeczny wymiar natury ludzkiej oznacza jakościowa nieokreśloność izolowanej jednostki, jej pustkę. Jak pisał Arystoteles, wspólnocie zawdzięczamy zdolność do życia rozumnego i dzielnego etycznie, a więc do spełniania swej gatunkowej funkcji: „Z natury swojej państwo jest pierwej aniżeli rodzina i każdy $z$ nas, całość bowiem musi być pierwej od części; po rozprzęgnięciu się całości nie będzie nogi ni ręki, a tylko nazwa [...]. Istota każdej rzeczy leży przecież w jej zadaniu praktycznym i zdolności jego wykonania"3. Tylko w społeczeństwie wiemy, kim jesteśmy, co znaczymy, jakie mamy cele i role. Wizja samego siebie odwzorowuje pozycje i zadania we wspólnocie. Poczucie własnej wartości jest refleksem społecznego szacunku. Postrzegamy się w perspektywie cudzych spojrzeń. Potrzebujemy bliźnich - choćby jako rywali lub niemych świadków własnej chwały. Immanuel Kant nazwał ten agonistyczny wariant skłonności społecznych „aspołeczną towarzyskościa”.

Gdy jednak Arystoteles mówił, że „człowiek jest $z$ natury stworzony do życia w państwie"5, wyrażał myśl znacznie głębszą niż

\footnotetext{
2 Platon, Państwo, przeł. W. Witwicki, Wydawnictwo „AKME”, Warszawa 1990, ks. II, 369 B-C, s. 102-103.

3 Arystoteles, Polityka..., ks. I, 1253a, s. 27-28.

4 Aspołeczna towarzyskość ludzi to „skłonność do życia społecznego, łącząca się jednak $z$ powszechnym oporem, który wciąż grozi rozbiciem społeczeństwa. Jest oczywiste, że zadatki tego leżą w naturze ludzkiej. Człowiek ma skłonność do uspołecznienia, ponieważ tylko w stanie społecznym czuje się bardziej człowiekiem [...]. Ale ma również wielką skłonność do odosabniania się (izolowania), ponieważ jednocześnie znajduje w sobie aspołeczną chęć urządzenia wszystkiego wedle własnego upodobania, [...] przezwycięża on swoją skłonność do lenistwa i gnany ambicja, żądzą władzy lub bogactwa, dąży do zdobycia sobie pozycji wśród bliźnich, których nie może znieść, ale bez których nie może się też obyć”. I. Kant, Pomysły do ujęcia historii powszechnej w aspekcie światowym, w: idem, Przypuszczalny poczatek ludzkiej historii, przeł. I. Krońska, Wydawnictwo "Comer”, Torun 1995, s. 39.

5 Arystoteles, Polityka..., ks. I, 1253a, s. 27.
} 
oczywisty fakt, że bez współpracy $z$ innymi nie moglibyśmy zaspokoić swoich potrzeb bytowych i bylibyśmy pozbawieni pierwiastka kulturowego, który zakorzenia nas w określonym miejscu hierarchii społecznej i pozwala toczyć wojny o uznanie. Społeczna natura człowieka ma przede wszystkim wymiar bezinteresowny. Oznacza niczym nieuzasadnione pragnienie obecności bliźnich, samoistna potrzebę społecznego otoczenia. Instynkt społeczny to niemotywowana względami utylitarnymi skłonność do kontaktów $z$ innymi ludźmi i potrzeba przynależności do wspólnoty.

Klasyczna typologia potrzeb psychicznych autorstwa Abrahama Maslowa ${ }^{6}$ uwzględnia tę społeczna potrzebę. Pragnienie społecznej akceptacji pojawia się zdaniem autora zaraz po zaspokojeniu najbardziej podstawowych potrzeb - fizjologicznych oraz zwiazanych $z$ bezpieczeństwem - i jest punktem wyjścia do potrzeb wyższych szacunku i samorealizacji. Uniwersalny charakter tej potrzeby ma uzasadnienie ewolucyjne. Trwajaca miliony lat ewolucja biologiczna hominidów nagradzała umiejętności społeczne, ponieważ zwiększały one szanse na przeżycie w warunkach, w jakich funkcjonowali ludzie pierwotni i ich bezpośredni poprzednicy, czyli w małych wspólnotach plemiennych.

\section{Samotność z wyboru}

Myślenie, jako dialogowanie $z$ soba samym, zakłada czasowe wycofanie się ze świata. Samotność o charakterze intelektualnym jest warunkiem autorefleksji, poznawczego samorozwoju. Tego rodzaju samotność jest niezbędna w życiu każdego człowieka jako istoty rozumnej. Jak pisze Hannah Arendt, „bycie samemu i pozostawanie w komunikacji z samym soba jest cecha charakterystyczna życia umysłu”. Myślenie zawsze dokonuje się w samotności, bez udziału

6 Zob. A. Maslow, Motywacja i osobowość, cz. 1, przeł. J. Radzicki, Wydawnictwo Naukowe PWN, Warszawa 2018, s. 47-138.

7 H. Arendt, Myślenie, przeł. H. Buczyńska-Garewicz, Czytelnik, Warszawa 2002, s. 117. 
innych osób, które sa w trakcie tej aktywności intruzami. Ich obecność jest zbędna, a nawet obciążająca. Samotności wymaga również medytacja, intymny kontakt jednostki $z$ własnym wnętrzem, światem przyrody lub Bogiem. Tego rodzaju doświadczenia wiążą się $z$ samotnością kontemplacyjną.

Myślenie, autorefleksja i medytacja sa procesami podejmowanymi okazjonalne i ograniczonymi w czasie. Po ich zakończeniu wracamy do społeczeństwa, by ponownie odnaleźć bliskość z innymi i odnowić zawieszone relacje międzyludzkie. Bywa również tak, że powrót do świata społecznego nie następuje i myślenie bądź kontemplacja staja się treścia życia. Tracimy wówczas radość kontaktów $z$ bliźnimi, a aktywność publiczna zastępowana jest przez życie teoretyczne. Świadomy wybór tego stanu jest zjawiskiem absolutnie wyjątkowym. Vita contemplativa jest udziałem nielicznych jednostek, które na skutek duchowych poszukiwań wewnętrznej harmonii wzniosły się ponad naturalne potrzeby i stłumiły instynkt społeczny.

Wśród filozofów najgłośniejszym apologeta samotności $z$ wyboru był Jan Jakub Rousseau. U kresu życia pisał: „Oto jestem sam na świecie, bez brata, bliźniego, przyjaciela, towarzysza, poza samym soba. [...] Samotny do końca życia, ponieważ tylko w sobie znajduję pociechę, nadzieję i spokój, nie powinienem i nie chcę zajmować się

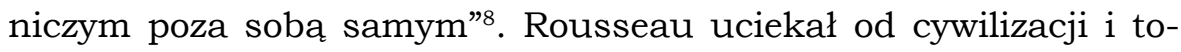
warzystwa ludzi. Choć odnosił spektakularne sukcesy i był jednym $z$ najbardziej pożądanych gości na salonach osiemnastowiecznej Europy, męczył go widoczny tam blichtr, który skrywał zepsucie, i kontakty społeczne, podszyte próżnością i rywalizacją o pozycję. Nic nie było tym, za co chciało uchodzić. Prawdziwe wytchnienie filozof znajdował dopiero w odosobnieniu:

Burzliwe życie nie zostawiało mi ani spokoju wewnętrznego, ani odpoczynku zewnętrznego. Na pozór szczęśliwy, nie doznawałem ani jednego uczucia, które mogłoby wytrzymać próbę refleksji i w którym naprawdę mógłbym

8 J.J. Rousseau, Przechadzki samotnego marzyciela, przeł. M. Gniewiewska, Czytelnik, Warszawa 1967, s. 25, 31. 
znaleźć upodobanie. Nie byłem nigdy zupełnie zadowolony ani z innych, ani $z$ samego siebie. Zgiełk świata mnie ogłuszał, samotność nudziła, czułem bezustanną potrzebę zmiany miejsca i nigdzie nie czułem się dobrze ${ }^{9}$.

Samotność dawała mu przestrzeń do swobodnej refleksji: „Te godziny samotności i rozmyślań sa jedynymi w ciagu dnia, gdy jestem w pełni soba i dla siebie, bez zakłóceń, bez przeszkód, i kiedy naprawdę mogę powiedzieć, że jestem tym, czego chciała natura"10. Prawdziwa jednak przyjemność znajdował nie w aktywności intelektualnej, a w bezrefleksyjnym marzycielstwie. Wspominajac momenty, w których czuł się prawdziwie spełniony i szczęśliwy, przywoływał samotne spacery wypełnione kontemplacja natury:

Zdarzało mi się rozmyślać dość głęboko, ale rzadko czyniłem to z przyjemnościa, prawie zawsze wbrew upodobaniu i jakby pod przymusem. Marzenie raduje mnie i daje wytchnienie, refleksja męczy i zasmuca; myślenie było dla mnie zawsze zajęciem nużącym i pozbawionym uroku. Niekiedy moje marzenia kończa się medytacją, ale częściej moje medytacje kończą się marzeniem i wówczas, w chwilach zapomnienia, dusza ma błaka się i szybuje we wszechświecie na skrzydłach wyobraźni, w zachwyceniu przewyższającym wszelka inną rozkosz. [...] Im czulszą duszę ma człowiek kontemplujący, tym bardziej pogrąża się w ekstazie, którą budzi w nim ta harmonia. Zmysły jego opanowuje wówczas słodkie i głębokie rozmarzenie; zatraca się on $z$ rozkosznym upojeniem $\mathrm{w}$ bezmiarze tego pięknego systemu, z którym czuje się utożsamiony. Wymykają mu się wtedy wszystkie poszczególne przedmioty, widzi i odczuwa wszystko tylko jako całość. [...] Nigdy nie rozmyślam, nie marzę rozkoszniej, niż kiedy zapominam o sobie. Odczuwam niewypowiedziane zachwyty, gdy mogę wtopić się, by tak rzec, w cały system istnień, utożsamić się $\mathrm{z}$ cała natura ${ }^{11}$.

Samotność, która pierwotnie była tylko ucieczka filozofa od zgiełku świata, wkrótce zaowocowała. Pomogła mu przemyśleć fundamentalne sprawy życiowe i zakosztować pierwotnej więzi z przyrodac. Ostatecznie zaś pozwoliła pogodzić się z samym sobą, ugruntować poczucie własnej wartości i uniezależnić się od opinii otoczenia:

\footnotetext{
Ibidem, s. 134.

Ibidem, s. 35.

Ibidem, s. 116-117, 121.
} 
Cofając się do mej duszy, przerywając stosunki zewnętrzne, które czyniły ją wymagająca, wyrzekając się porównań i szczególnych względów, zadowoliła się tym, żebym był dobry dla samego siebie, powróciła do naturalnego porządku świata i wyzwoliła mnie spod jarzma opinii ${ }^{12}$.

Zdany tylko na siebie, żywię się, to prawda, tylko własna substancja, ale ona się nie wyczerpuje, wystarczam sobie ${ }^{13}$.

Zdany na samego siebie, odnalazłem wreszcie grunt pod nogami ${ }^{14}$.

Samotny wśród nich, w sobie tylko znajduję oparcie ${ }^{15}$.

Uczniem Rousseau pod interesujacymi nas względami był amerykański pisarz i myśliciel Henry David Thoreau, który na pewnym etapie życia zdecydował się na długotrwałe odosobnienie i na ponad dwa lata osiadł samotnie w leśnej chacie ${ }^{16}$. Pisał wówczas:

Zamieszkałem w lesie, albowiem chciałem żyć świadomie, stawiać czoło wyłącznie najbardziej ważkim kwestiom, przekonać się, czy potrafię przyswoić sobie to, czego może mnie nauczyć życie, abym w godzinie śmierci nie odkrył, że nie żyłem. Nie chciałem prowadzić życia, które nim nie jest, wszak życie to taki skarb; nie chciałem też rezygnować $z$ niczego, chyba że było to absolutnie konieczne. Pragnąłem żyć pełnia życia i wyssać z niego całą kwintesencję, żyć tak śmiało i po spartańsku, aby wykorzenić wszystko, co nie jest życiem, aby zbierać bogaty plon i dosięgać sedna, aby zapędzić życie w kozi róg i uprościć je do najskromniejszych potrzeb ${ }^{17}$.

Thoreau uważał, że człowiek nie potrzebuje społeczeństwa ${ }^{18}$. Samotność jest stanem naturalnym, charakteryzującym większość tworów przyrody: „Nie jestem bardziej samotny aniżeli rosnąca w pojedynkę na pastwisku dziewanna czy mlecz, ani też liść fasoli,

\footnotetext{
Ibidem, s. 140.

Ibidem, s. 134.

14 Ibidem, s. 127.

15 Ibidem, s. 141.

16 Pisarz wybudował sobie bardzo skromna jednoizbową chatkę w lesie nad stawem Walden. Mieszkał w niej dwa lata, dwa miesiące i dwa dni (od 4 lipca 1845 do 6 września 1847 roku), samodzielna praca zaspokajając wszystkie podstawowe potrzeby. Swoje życie nad stawem opisał w głośnej ksiażce Walden, czyli życie $w$ lesie (Walden; or, Life in the Woods, 1854).

17 H.D. Thoreau, Walden, czyli życie w lesie, przeł. H. Cieplińska, Państwowy Instytut Wydawniczy, Warszawa 1991, s. 121-122.

18 Ibidem, s. 188.
} 
szczaw, giez koński czy trzmiel"19. Oddalenie od wspólnoty chroniło go przed męczącym towarzystwem nieciekawych osób.

Towarzystwo to przeważnie rzecz tandetna. Spotykamy się po bardzo krótkich przerwach, kiedy upłynęło jeszcze zbyt niewiele czasu, abyśmy mogli zyskać dla siebie nowa wartość. [...] żyjemy w ciasnocie, wchodzimy sobie $\mathrm{w}$ drogę i potykamy się o siebie, tracąc tym samym, mam wrażenie, po trosze wzajemny szacunek. Rzadsze spotkania $z$ pewnościa zaspokoiłyby nasza potrzebę utrzymywania ważnych i serdecznych kontaktów. Weźmy robotnice fabryczne - nigdy same, prawie nigdy nie pograżone w marzeniach. Lepiej by było, gdyby na jedna mile kwadratowa przypadał tylko jeden człowiek, podobnie jak tu, gdzie ja mieszkam ${ }^{20}$.

Dzięki ograniczeniu potrzeb materialnych do niezbędnego minimum pisarz miał dużo wolnego czasu. Wypełniał go lektura książek, rozmyślaniami i medytacją. Potrafił wiele godzin spędzić bezczynnie, kontemplując naturę. Cenił te momenty bezruchu bardziej niż czas poświęcony konkretnej pracy:

Bywały takie letnie dni, gdy wziąwszy jak zwykle kapiel, cały poranek - od wschodu do południa - spędzałem, siedzac w słońcu na progu, zatopiony w myślach, pośród sosen, hikor i sumaków, w niezmąconej samotności i spokoju, [...] dawał mi on więcej zadowolenia, aniżeli gdybym wykonywał jakakolwiek pracę rękami. Nie był to czas, który należałoby odjąć z mojego życia, lecz dodany do niego i o wiele bogatszy. Zdałem sobie sprawę $z$ tego, co ludzie Wschodu rozumieja przez kontemplację i zaniechanie zajęć ${ }^{21}$.

Zwraca uwagę duże podobieństwo między Rousseau i Thoreau w zakresie wielu osobistych doświadczeń, upodobań i skłonności. Obu myślicieli łączy pozytywne doświadczenie samotności, marzycielstwo, wrażliwość na piękno przyrody, odmowa udziału w wyścigu społecznym czy otwarty konflikt $z$ ówczesnym państwem. Obaj byli romantykami w punkcie wyjścia, zaś u kresu życia stali się mizantropami. Ich desperacka próba znalezienia własnego

19 Ibidem, s. 174.

20 Ibidem, s. 173.

21 Ibidem, s. 145. 
miejsca w zastanych realiach społecznych i politycznych zakończyła się ucieczką, odrzuceniem społeczeństwa i indywidualnym powrotem do stanu natury ${ }^{22}$.

\section{Wladza}

Społeczny wymiar natury ludzkiej jest faktem empirycznym. Jako gatunek zawdzięczamy mu przetrwanie. Warto jednak mieć też świadomość pewnych negatywnych konsekwencji tego wymiaru. Nasze potrzeby wystawiaja nas na kaprysy tych, którzy potrafia je zaspokoić. Pragnienia daja władzę dysponentowi poszukiwanych dóbr. Pożądanie uzależnia od obiektu pożądania.

Starożytni dostrzegali tę formę zniewolenia duszy. Niewola wewnętrzna skupiała uwage filozofów bardziej niż jakakolwiek postać niewoli zewnętrznej, ponieważ środki zaradcze były powszechnie osiagalne: wyzwolenie leżało $\mathrm{w}$ rękach każdego $\mathrm{z}$ nas. Arystoteles postulował, aby źródeł szczęścia szukać w sobie, a nie w dobrach oferowanych przez nieprzewidywalne otoczenie czy los: „Przypisywanie [...] przypadkowi tego właśnie, co jest najważniejsze i moralnie najpiękniejsze, byłoby szczytem niedorzeczności"23. Bardzo popularnym wzorcem etycznym (również w późniejszych epokach) był stoicki mędrzec, który poprzez dyscyplinę wewnętrzną uniezależnił się od czynników zewnętrznych. Opanowując pożądania i rezygnując $z$ dóbr, nad którymi nie miał kontroli, osiągnął on wewnętrzną harmonię i spokój.

Gdy odczuwana potrzeba jest podstawowa i można ja zaspokoić wyłącznie u jednego źródła, władza nad jednostką staje się absolutna. $Z$ taka sytuacja mamy do czynienia w odniesieniu do potrzeby kontaktów społecznych. Spełnione są w tym wypadku oba wymie-

\footnotetext{
22 Obu autorów łączy również krytyka zbytku, pochwała spartańskiego modelu życia, lekceważenie rozumu i naukowej drogi poznania, krytyka nierówności społecznych i zastanego układu sił oraz percepcja dziejów ludzkości jako historii upadku.

${ }^{23}$ Arystoteles, Etyka nikomachejska, w: idem, Dzieła wszystkie, t. 5, przeł. D. Gromska, Wydawnictwo Naukowe PWN, Warszawa 1996, ks. I, 1099b, s. 93.
} 
nione kryteria: po pierwsze, potrzeba przynależności ma w strukturze ludzkich potrzeb charakter fundamentalny, a po drugie, w warunkach tradycyjnego ładu zaspokoić ja można tylko poprzez akceptację ze strony najbliższej wspólnoty. Społeczność, do której należymy, ma monopol na udzielenie nam społecznego wsparcia. Dobro to możemy otrzymać tylko u jednego dostawcy. Dysponuje on w ten sposób potężna bronia - ma władzę akceptowania i wykluczania, uznawania i marginalizowania, wywyższania i napiętnowania.

\section{Lęk}

Lęk przed środowiskowym ostracyzmem to jeden $z$ najsilniejszych ludzkich stymulatorów negatywnych. Społeczna separacja jest dla zdrowej osoby źródłem wielkiego cierpienia - stanem nie do zniesienia ${ }^{24}$.

Zwróćmy uwage na rolę kary izolacji więziennej. Pobyt w celi $z$ innymi współwięźniami to ograniczenie wolności i jako taki jest powszechnie akceptowana kara stosowana wobec przestępców. Inaczej ocenia sie jednak długotrwałe przebywanie w pojedynczej celi. Uznawane jest ono za przykład traktowania nieludzkiego. Okrucieństwo tej formy kary dostrzegał już Karol Dickens, który podróżując w 1842 roku po Stanach Zjednoczonych, odwiedził więzienie stanowe w Filadelfii (Pensylwania), gdzie stosowano karę samotnego pobytu w celi:

Sązę, że tylko bardzo nieliczni ludzie potrafia ogarnąć cały ogrom tortury i udręki, jaki zadaje swym ofiarom ta straszliwa kara, trwająca lata. A że się domyślam oraz wyciagam wnioski $z$ tego, co widziałem wypisane na twarzach tych ofiar, a co, jak wiem $z$ pewnościa, odczuwają one w głębi duszy, tym bardziej więc jestem przekonany, że kryje ona w sobie cała otchłań okropnego cierpienia, którego nikt nie zdoła zgłębić prócz jego ofiar, a którego żaden człowiek nie ma prawa narzucać bliźniemu. Uważam takie podstępne i codzienne machinacje $z$ tajnikami mózgu za stokroć gorsze od

24 Zob. H. Arendt, Myślenie..., s. 118. 
wszelkiej tortury ciała. [...] Jestem mocno przekonany, ze niezależnie od męczarni tak dotkliwej i tak strasznej, że żadne o niej wyobrażenie nie dorówna rzeczywistości, kara ta doprowadza umysł więźnia do stanu chorobliwego, co czyni go niezdolnym do brutalnego zetknięcia się ze światem i żywym biegiem spraw na nim. Mam mocno utwierdzone przekonanie, że ludzie, którzy ponieśli tę karę, muszą wrócić do społeczeństwa moralnie wykolejeni i schorzali ${ }^{25}$.

Długotrwałe przebywanie w pojedynczej celi prowadzi do zaburzeń psychicznych. U więźniów poddanych takiej karze obserwuje się halucynacje wzrokowe i omamy słuchowe, depresję, wzrost agresji, brak kontroli nad emocjami, trudności z myśleniem, pamięcią i koncentracja oraz zachowania autodestrukcyjne, na przykład samookaleczenia i próby samobójcze ${ }^{26}$. Całkowita izolacja więźnia może być interpretowana jako tortury i łamanie praw człowieka. Zakazuje jej między innymi Europejska Konwencja Praw Człowieka ${ }^{27}$. Europejski Komitet do spraw Zapobiegania Torturom oraz Nieludzkiemu lub Poniżajacemu Traktowaniu albo Karaniu (CPT) stwierdza, że izolacja jako kara dyscyplinarna nie powinna trwać dłuższej niż czternaście dni ${ }^{28}$.

\footnotetext{
${ }^{25}$ K. Dickens, Notatki z podróży do Ameryki, przeł. B. Czerwijowska, Państwowy Instytut Wydawniczy, Warszawa 1978, s. 112, 122. Zauważmy, że w USA nadal praktykuje się długotrwałe przebywanie w izolatkach $\mathrm{w}$ ramach sankcji dyscyplinarnej wobec więźniów uznanych za niesubordynowanych. Obecnie w celach odosobnienia przebywa w tym kraju około osiemdziesiąt tysięcy więźniów, a średnia długość pobytu w karcerze wynosi kilka lat. W więzieniu stanowym w Kolorado kilkuset więźniów przebywa w pozbawionych okien pomieszczeniach o powierzchni kilku metrów kwadratowych. Najkrótszy pobyt w izolatce trwa tam osiemnaście miesięcy, ale niektórzy pozostaja w niej do końca życia. Zob. Życie w więziennej izolatce, reż. P. Yost, 2010 - film będący relacja z corocznego badania więźniów przez Departament Więziennictwa stanu Kolorado.

26 Zob. S. Grassian, Psychiatric Effects of Solitary Confinement, „Washington University Journal of Law \& Policy" 2006, vol. 22, p. 325-383.

27 Europejska Konwencja Praw Człowieka w art. 3 głosi: „Nikt nie może być poddany torturom ani nieludzkiemu lub poniżającemu traktowaniu albo karaniu" (https://www.echr.coe. int/Documents/Convention_POL.pdf). Na ten artykuł powołał się norweski terrorysta Andres Breivik, który po zabiciu 77 osób otrzymał wyrok 21 lat więzienia. Po prawie trzech latach pobytu w zakładzie karnym pozwał Norwegię za stosowanie wobec niego tortur w postaci osadzenia w pojedynczej celi. W 2016 roku sąd pierwszej instancji uznał jego racje i Breivik wygrał proces, ale w 2017 roku sąd apelacyjny unieważnił ten werdykt.

28 CPT zaleca „ograniczenie osadzenia w warunkach izolacyjnych do absolutnego minimum, tak aby zapewnić, że jeśli jest ono stosowane, to na najkrótszy niezbędny czas, by uczynić każdy $z$ reżimów izolacyjnego osadzenia tak pozytywnym, jak to tylko możliwe i zagwaranto-
} 


\section{Uległość}

Skoro lęk przed samotnością podporządkowuje jednostkę otoczeniu i emocjonalnie uzależnia, to w pewnych okolicznościach może doprowadzić do zachowań konformistycznych. $Z$ obawy przed odrzuceniem ulegamy presji środowiskowej. Potrzeba przynależności jest tak silna, że stajemy się bezmyślnym trybikiem w społecznym mechanizmie. Działamy wbrew własnym przekonaniom, niezgodnie ze wskazaniami sumienia. Rezygnujemy $z$ autonomii moralnej. Przestajemy być indywidualnym podmiotem decyzji. Odgrywamy role wyznaczone przez wspólnotę. W skrajnych warunkach, na przykład wojennych czy więziennych, może to być rola kata lub biernego świadka ludobójstwa.

Zdaniem Arendt za największymi zbrodniami XX wieku stoi ten właśnie mechanizm depersonalizacji sprawcy i banalizacji zła. Jako amerykańska korespondentka relacjonowała ona w 1961 roku odbywający się w Jerozolimie proces Adolfa Eichmanna, nazistowskiego funkcjonariusza odpowiedzialnego za praktyczna realizację Holocaustu. W 1963 roku opublikowała bazujaca na obserwacjach z procesu książkę ${ }^{29}$. Ekstremalne zło czynione przez nazistów w czasie drugiej wojny światowej nie miało jej zdaniem wymiaru demonicznego, nie ujawniło mrocznych stron natury ludzkiej. Eichmann nie był sadysta, socjopata mającym upodobanie w zadawaniu cierpienia. Jak zeznał przed sądem, swoje zawodowe obowiazki w departamencie odpowiedzialnym za kwestię żydowską Głównego Urzędu Bezpieczeństwa Rzeszy wykonywał bez przyjemności. Podobno nie był nawet antysemita.

Przyczyna zła, którego ofiarą padły dziesiątki milionów ludzi, była banalna: potrzeba przynależności, bezmyślność, zanik

wać, że istnieja procedury pozwalające na użycie tego środka tylko wtedy, gdy jest to w pełni uzasadnione". Izolacja osadzonych. Wyciag z Dwudziestego Sprawozdania Ogólnego CPT, 2011, s. 1 (https://rm.coe.int/16806ccbf).

29 H. Arendt, Eichmann w Jerozolimie. Rzecz o banalności zła, przeł. A. Szostkiewicz, Społeczny Instytut Wydawniczy „Znak”, Kraków 1987. 
indywidualnej podmiotowości moralnej i poczucia odpowiedzialności za własne czyny, uległość wobec przełożonych, szacunek wobec siły i autorytetu ${ }^{30}$. Jak pisała Arendt o Eichmannie:

Nie był głupcem. To czysta bezmyślność - której bynajmniej nie należy utożsamiać z głupota - predysponowała go do odegrania roli jednego z największych zbrodniarzy tamtego okresu. Jeśli zaś jest to „banalne” czy wręcz śmieszne, jeśli nawet przy najlepszej woli nie sposób odkryć u Eichmanna żadnej diabelskiej czy demonicznej głębi, daleko tu jeszcze do nazwania tego czymś zwyczajnym. [...] Na tym, że tak zupełne oderwanie od rzeczywistości i taka bezmyślność moga spowodować większe spustoszenie niż wszystkie złe instynkty razem wzięte, a przyrodzone być może człowiekowi - na tym właśnie polegała w istocie lekcja, jakiej można było nauczyć się w Jerozolimie ${ }^{31}$.

Badania $z$ zakresu psychologii społecznej potwierdzaja obserwacje niemieckiej filozofki. Eksperymenty Stanleya Milgrama badające posłuszeństwo wobec autorytetu (1961) i ich liczne późniejsze warianty, stanfordzki eksperyment więzienny Philipa Zimbardo (Stanford Prison Experiment, 1971), eksperymenty Muzafera Sherifa i Salomona Ascha dotyczące konformizmu czy badania strażników z obozów koncentracyjnych Johna Steinera wykazały, że zdecydowana większość społeczeństwa - niezależnie od narodowości, płci i wieku - wykazuje daleko posunięty konformizm, gotowość spełniania oczekiwań otoczenia i ulegania zewnętrznym autorytetom. Zwyczajni ludzie umieszczeni w odpowiednim kontekście społecznym zdolni sa do niezwykłego okrucieństwa. Jako strażnicy więzienni znęcają się nad więźniami (eksperyment Zimbardo), a jako nauczyciele wypełniaja polecenia przełożonego i stosuja tortury wobec niewinnych uczniów (eksperymenty Milgrama).

\footnotetext{
30 „Do samego końca Eichmann żarliwie wierzył w sukces, który wedle jego wyobrażeń stanowił główną normę obowiązującą w "lepszym towarzystwie». Typowe są uwagi dotyczące Hitlera [...]: «mógł się całkowicie mylić, ale jedno nie podlega dyskusji: potrafił zapewnić sobie awans $z$ kaprala armii niemieckiej na führera liczącego prawie 80 milionów ludzi narodu. [...] Sam ten sukces był dla mnie dowodem, że powinienem podporządkować się temu człowiekowi"”. Ibidem, s. 161-162.

31 Ibidem, s. 371.
} 
Tak jak masowy współudział Niemców w zbrodni nie obnażył zdaniem Arendt żadnej narodowej patologii, tak powszechna uległość Żydów i ich skrupulatność w wypełnianiu poleceń oprawców nie zdemaskowała jakiejś ułomności w ich charakterze. Żydom w zaistniałym podczas drugiej wojny światowej układzie społecznym przypadła rola ofiary, do której zaadaptowali się na miarę swych umiejętności. Ich zachowanie, podobnie zreszta jak innych podbitych narodów, pokazuje, że równie łatwo jak złoczyńca stajemy się poszkodowanym:

Żydzi szli na śmierć - a przybywali punktualnie do miejsc, skąd odchodziły transporty, dobrowolnie udawali się na miejsca egzekucji, sami kopali sobie groby, rozbierali się i układali ubrania w równe stosiki, a potem kładli się ramię przy ramieniu, czekając na wystrzał. [...] Gdyby nie pomoc Żydów w pracy administracyjnej i działaniach policji [...] zapanowałby kompletny chaos bądź też doszłoby do poważnego obciażenia niemieckiej siły roboczej. [...] Zarówno w Amsterdamie, jak w Warszawie, w Berlinie, tak samo jak w Budapeszcie można było mieć pewność, że funkcjonariusze żydowscy sporzadza wykazy imienne wraz $z$ informacjami o majatku, zagwarantuja uzyskanie od deportowanych pieniędzy na pokrycie kosztów ich deportacji i eksterminacji, będą aktualizować rejestr opróżnionych mieszkań, zapewnia pomoc własnej policji w chwytaniu i ładowaniu Żydów do pociągów ${ }^{32}$.

Uległość jest cechą natury ludzkiej wzmacnianą przez wychowawców i otoczenie w trakcie socjalizacji. Będąc elementem wspólnoty, poznajemy swoje miejsce i uczymy się respektować zdanie przełożonych. Bunt zawsze jest bardzo trudny. Jak pisze Per Herngren, szwedzki aktywista pacyfistyczny i uczestnik wielu akcji obywatelskiego nieposłuszeństwa na rzecz powszechnego rozbrojenia: „Myś1 o łamaniu prawa i ogólnie przyjętych konwencji ciąży [...] niczym kajdany. Nie jest to jedynie bariera psychologiczna. Jest to także pewien narzucony przez społeczeństwo sposób funkcjonowania"33. Herngren wspomina własne doświadczenia w opanowywaniu głęboko

32 Ibidem, s. 16, 150-151.

33 P. Herngren, Podstawy obywatelskiego nieposłuszeństwa, przeł. E. Borkowska-Stich, A. Parzniewska, Wydawnictwo „Zielone Brygady”, Kraków 1997, s. 115. 
zakorzenionej w psychice ludzkiej uległości: „Spędziwszy rok na tułaczce po dziesiątkach amerykańskich więzień, zrozumiałem, jak ciężka jest walka $z$ posłuszeństwem, walka $z$ własnym strachem, walka, która jest skierowana przeciwko nam samym. [...] Obcując $z$ innymi ludźmi, nauczyłem się posłuszeństwa. Dzisiaj muszę uczyć się $z$ nim walczyć"34.

\section{Jednostka}

Indywidualizm oparty jest na przekonaniu, że każda dorosła jednostka jest zdolna do samodzielnego, kreatywnego i aktywnego życia. Poszczególni ludzie sa sprawczy w swoich decyzjach i czynach. Podejmuja własne odpowiedzialne wybory, bez wsparcia odgórnie zorganizowanych instytucji czy spontanicznie powstałych wspólnot. Jednostka jest ontologicznie pierwsza i znaczeniowo nadrzędna w stosunku do wszelkich zbiorowości. Społeczeństwo jest wtórne i ma charakter instrumentalny. Indywidualizm jest apoteoza przebojowości i sił witalnych. Poddanie, bierność i uległość nie pasują do indywidualistycznego wzorca. Reaktywny sposób postępowania, podporządkowanie i poświęcenie uchodzą w indywidualistycznej ideologii za niestosowne. Konformizm kłóci się $z$ wyznawanymi ideałami.

Istnieje wyraźna sprzeczność pomiędzy koncepcją człowieka jako indywiduum w pełni odpowiedzialnego za swe czyny a wizja człowieka społecznego, zależnego od wspólnoty i zdanego na jej werdykty. Jak w perspektywie empirycznej ocenić powyższe założenia indywidualistyczne? Czy Kantowska koncepcja podmiotowości moralnej, republikańska idea obywatelskiego zaangażowania i politycznej odpowiedzialności, liberalny indywidualizm sa wyłącznie utopijnymi kreacjami?

Powyższa sprzeczność znika, gdy oddzielimy sferę deskrypcyjna od normatywnej. Fakty ukazuja jednostkowa niesamodzielność,

34 Ibidem, s. 9-10. 
potrzebę usytuowania i znalezienia sensu w ramach większej całości. W warstwie postulatywnej możemy jednak formułować obowiązki etyczne i prawne zakładające podmiotowość jednostki. Przywołajmy opinię Arendt na temat odpowiedzialności Eichmanna. Dyskusję toczącą się w Sądzie Okręgowym w Jerozolimie między obrońca Eichmanna i prokuratorem komentuje ona następująco:

Usłyszeliśmy tam sprzeciwy obrony, twierdzącej, że Eichmann był przecież jedynie „trybikiem” w maszynie Ostatecznego Rozwiazania, a także sprzeciwy oskarżenia, które uważało, iż był on w rzeczywistości jej siłą napędową. Osobiście nie przywiazywałam do obu tych tez większego znaczenia, niż uczynił to sąd jerozolimski, ponieważ teoria trybika nie ma $z$ prawnego punktu widzenia najmniejszego sensu [...] - wszystkie tryby machiny, choćby najmniej istotne, ulegaja przed sądem przeistoczeniu w sprawców czynu, to znaczy w istoty ludzkie ${ }^{35}$.

Pomimo wzajemnego uwikłania i skomplikowanych relacji międzyludzkich, w obliczu ważnych decyzji życiowych możemy zasadnie zawiesić regułę społecznego determinizmu. Każda jednostka $\mathrm{w}$ istotnych chwilach swojego życia staje się decydentem. Za każdym czynem i zaniechaniem stoi świadoma, wolna jednostka. Nawet jeśli w rzeczywistości postępuje rutynowo czy emocjonalnie, to i tak mamy prawo postrzegać ja jako podmiot moralny i pociagać do indywidualnej odpowiedzialności.

W każdym człowieku istnieje potencjał do zachowań autonomicznych, nieposłusznych. Rzadko wykorzystywany, niemniej obecny, stanowi uniwersalne zaplecze naszych możliwości sprawczych i obowiązków etycznych. Poziom indywidualnej podmiotowości moralnej jest dla nas wyzwaniem, celem wysiłków. W takiej interpretacji ma szansę stać się poszukiwanym remedium na zgubne skutki społecznego podporzadkowania.

35 H. Arendt, Eichmann..., s. 372-373. 


\section{The Social Dimension of Human Nature: Consequences and Challenges}

We are social beings. Facts show that an individual is not independent and needs to situate oneself and find meaning within a larger whole. The acceptance of this thesis should be accompanied by the awareness of threats arising from the social dimension of human nature. While desires make us dependent on the objects of desire, our social needs make us dependent on society. For fear of exclusion, we agree to play roles contrary to our conscience. On the other hand, every human being has a potential for autonomous, individual and disobedient behaviour. Rarely used, yet present, it constitutes a universal base for our causative capabilities and ethical obligations. The level of individual moral subjectivity is a challenge for us and the goal of our efforts. Interpreted in this way, it has a chance to become a desired remedy for the damaging effects of social subordination.

Keywords: individualism, punishment of isolation, conformism, fear of exclusion, subordination, loneliness, loneliness by choice, submission, community power. 